\title{
Impact of blue economy factors on economic growth in the SAARC countries
}

\author{
Majed Alharthi \\ Department of Finance, College of Business, King Abdulaziz University, \\ Rabigh, Saudi Arabia, and \\ Imran Hanif \\ Department of Economics, University of Management and Technology, \\ Lahore, Pakistan
}

Economic growth in the SAARC countries

\begin{abstract}
Purpose - This study aims to examine the influence of the blue economy factors on the economic growth of the South Asian Association for Regional Cooperation (SAARC) countries.

Design/methodology/approach - Secondary data from 1995 to 2018 have been used for the analysis of eight countries. The contributing factors that measure the fishing production are total aquaculture production, total fisheries production and agriculture, forestry and fishing. Trade and the rate of inflation are used as control variables. Using the feasible generalized least square technique.

Findings - It was found that the blue economy factors play a statistically significant role in the economic growth of SAARC countries and contribute to the achievement of Goal 14 of the United Nations' sustainable development goals: to conserve and sustainably use the oceans, seas and marine resources for sustainable development.

Originality/value - This study highlights the fact that proper management and utilization of water resources may assist the stimulation of economic growth and meet the challenges of food insecurity by improving the supply of seafood in developing South Asian countries. The study proposes that the sustainable management of water resources requires an alliance across nation states. The alliance will be useful in understanding the concept of the blue economy and the role it plays in ensuring economic growth in developing nations throughout the world.
\end{abstract}

Keywords Aquaculture and fishing, Blue economy, Economic growth, Fishing production, Gross domestic product

Paper type Research paper

\section{Introduction}

The European commission defines the blue economy as "all economic activities related to oceans, seas and coasts. It covers a wide range of interlinked established and emerging sectors". (European Union, 2018). The world's oceans, coastal areas and seas are the largest ecosystems on the planet, with the oceans covering two-thirds of the planet's surface. These ecosystems are vital for both planetary and human health. Oceans not only help buffer the effects of climatic changes but also provide habitats for millions of species and food for more than one billion people (Parletta, 2019). Oceans are also vital to the economic prosperity of

(C) Pacific Star Group Education Foundation. Licensed re-use rights only.

This paper forms part of special section "Sustainability challenges in maritime financings", guest edited by Faris Alshubiri and Mohamed Elheddad.

Received 16 January 2020

Revised 28 March 2020

5 April 2020

8 April 2020

Accepted 8 April 2020 
MABR

5,3

most countries. Despite the fact that oceans are a precious aspect of our natural heritage, only $7 \%$ of the planet's oceans have been explored (Toropova et al., 2010). In the context of global megatrends such as migration to coastal cities, population growth, energy demands and climate change, the relationship between humanity and the oceans is becoming more complex. Given the rapid pace of urbanization, climate change, population growth and other land-based issues, the focus of global policy discussions is shifting gradually toward the world's blue resources. If these resources are managed sustainably, they will have positive economic and environmental implications (Singh, 2019). The blue economy, despite being an emerging concept, has already become a priority for the European Union and for the development agenda of Africa and efforts are being made to bring other regions on board to strengthen and better manage the blue economy within and across continents. Promoting and strengthening the blue economy holds immense promise for South Asia, which is a hub of world trade. However, the region is also faced with a multitude of socio-economic challenges. In this context, a blue economy offers a pathway to addressing some of these challenges. The South Asian region holds special social, economic and political importance as one of the most populated areas in the world (Bose and Jalal, 2017). The South Asian Association for Regional Cooperation countries (SAARC) countries Afghanistan, Bangladesh, Bhutan, India, Nepal, Pakistan, Sri Lanka and the Maldives - have a combined population of approximately 1.9 billion (World Bank, 2019). South Asia is one of the largest and poorest regions in the world. In spite of its extensive human and natural resources, the region is underdeveloped (Jayawardena et al., 2013), the quality of life is poor and the infant death rate is very high (Khan, 2005).

This study represents an attempt to highlight the trajectory from the blue economy to economic growth for the South Asian countries under consideration. The first and foremost indicator of the growth of any economy is its gross domestic product (GDP) (Henderson et al., 2011; Wong et al., 2005). GDP is the sum of the gross value of all resident producers in the economy plus any product taxes (Murry and Nan, 1994) and GDP per capita is a country's GDP divided by the population of that country (Hoshino, 2011). GDP per capita provides insight into how much is being spent on each person in a particular country and is used to calculate the performance of that country's economy [Organization for Economic Co-operation and Development (OECD, 2017)]. According to the World Bank (2019), the GDP per capita of South Asia was $\$ 1,907$ in 2018, which is only marginally higher than that of African countries. South Asian countries are densely populated. India and Pakistan have large populations and Pakistan's income distribution is excessively unbalanced. The middle class of society is shrinking constantly, with the poor becoming poorer and the rich becoming richer.

The South Asian region is progressing slowly and steadily. In addition, the estimated GDP growth of South Asian countries dropped by 1.1\% in 2019 compared to the previous year (World Bank, 2019). According to policymakers, the maximum retrieval could be up to $6.3 \%$ for 2020 and $6.7 \%$ for 2021. Only two South Asian nations, Sri Lanka and the Maldives, have healthy GDPs per capita (World Bank, 2019). Both countries are investing in the tourism industry and implementing strategies to manage income distribution. These strategies are paying off. Table 1 provides the actual and expected GDP growth for South Asian countries.

The GDP growth of Afghanistan is forecasted to improve because of improvements in the country's cultivation practices. However, this is dependent on political circumstances and the stability of the region. Comparatively, the GDP growth of Bangladesh is forecast to decrease by $7.3 \%$ due to the uncertainty and fragility of the financial sector. Nevertheless, Bangladesh may be able to keep the growth rate above $7 \%$ with the help of increased government spending and stable political conditions. GDP growth in India is predicted to fall to $6 \%$ this fiscal year due to an extended downturn in the first quarter of 2020 . It is forecast to be $6.9 \%$ in the fiscal year 2020. In the Maldives, GDP growth was $5.2 \%$ at the end 
of 2019 because of the development of Maldives International Airport. Nevertheless, with the help of increased financing and tourism, the GDP of the Maldives may rise to $5.6 \%$ over the projected years. The forecast GDP growth of Nepal is approximately $6.5 \%$, supported by increased employment and developmental work. Pakistan's GDP is expected to decrease by $3.3 \%$ in 2020 . However, its contract with the International Monetary Fund is expected to help revive its economy.

Coasts and seas are the most gainful biological systems on earth and represent effective resources that can strengthen financial and economic development (Voyer and van Leeuwen, 2019). Climate guidelines, shoreline adjustments, carbon sequestration, fisheries, hydroelectric energy, wind energy, ocean-based oil and gas resources and the travel industry all contribute between $\$ 3 \mathrm{tn}$ and $\$ 5 \mathrm{tn}$ annually (Everest-Phillips, 2014). Thus, improvement in the blue economy can positively affect a country's economic growth, if looked after effectively (Eikeset et al., 2018). Scholars and international organizations believe that the blue economy is sustained by three elements, namely, the development of the marine economy (Behnam, 2012), the innovative development of the economy (Pauli, 2010) and coping with the global water crisis (McGlade et al., 2012). Fortunately, many organizations, communities and governments are becoming aware of the need for a more coherent, integrated, fair and scientific approach to the management of the economic development of the oceans (Smith-Godfrey, 2016). Moreover, humanity increasingly understands that it is an integral part of the oceans and ecosystems and must accordingly plan and implement its economic activities with care, balancing the desire to improve human living standards and sustain a healthy marine ecosystem.

The convergence of the blue economy and the marine ecosystem means that ecosystem accounting is closely linked to economic growth (Lillebø et al., 2017). Mulazzani et al. (2016) presented the ecosystem service management framework to address coastal economic growth. Kathijotes (2013) argued that the principal aim of the blue economy model is to tackle the issues that cause environmental problems and shift resources from scarcity to abundance. Van-den-Burg et al. (2019) proposed possible boundaries for the growth of the marine industry. According to Soma et al. (2018) and Keen et al. (2018), economic growth can be achieved through inclusion, collaboration and trust. In a similar study, Sarker et al. (2018) emphasized the development of a management framework of blue growth that should promote the blue economy and ensure economic development. Howard (2018) presented an in-depth discussion of the role of stakeholders in economic development.

\begin{tabular}{lcccc}
\hline Country name & $2018(\%)$ & $2019(\mathrm{e})(\%)$ & $2020(\mathrm{f})(\%)$ & $2021(\mathrm{f})(\%)$ \\
\hline Afghanistan (CY) & 1.8 & 2.5 & 3.0 & 3.5 \\
Bangladesh (FY) & 7.9 & 8.1 & 7.2 & 7.3 \\
Bhutan (FY) & 4.6 & 5.0 & 7.4 & 5.9 \\
India (FY) & 6.8 & 6.0 & 6.9 & 7.2 \\
Maldives (CY) & 6.7 & 5.2 & 5.5 & 5.6 \\
Nepal (FY) & 6.7 & 7.1 & 6.4 & 6.5 \\
Pakistan (FY and factor price) & 5.5 & 3.3 & 2.4 & 3.0 \\
Sri Lanka (CY) & 3.2 & 2.7 & 3.3 & 3.7
\end{tabular}

Sources: World Bank (2019). GDP: gross domestic product, CY: calendar year, FY: fiscal year, e: estimate f: forecast; in Bangladesh, Bhutan, Nepal and Pakistan, 2019 refers to FY2018/2019 and ended in June 2019. For India, 2019 refers to FY2019/2020 and will end in March 2020

\section{Economic growth in the SAARC countries}

255

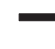


MABR

5,3

It is important to note that oceans are reaching a tipping point on many fronts, from overfishing and marine pollution to coastal erosion, which is exacerbated by climate change. Healthy oceans provide jobs and food, drive economic growth and keep the planet from overheating (Mulazzani et al., 2016). Interdisciplinary and multidisciplinary research is important when studying blue economies, with one of the main challenges being how to integrate the blue economy with wider economic growth (Golden et al., 2017). Against this backdrop, this study aims to discuss aquaculture, fisheries, marine tourism and the role of agriculture, forestry and fishing (AFF) in ocean resource management. The study seeks to investigate the role that the blue economy plays in the economic growth of South Asian countries and looks to emphasize how the concept of the blue economy fits into the economic development framework. The study will help policymakers, investors and governments better understand current trends and emerging threats to oceans and identify appropriate action-based solutions. The findings will also help researchers enhance their knowledge of this subject. In short, this study will provide the answer to an important research question:

$R Q 1$. How does the blue economy contribute to the economic growth of South Asian countries?

The remainder of the study is organized as follows:

Section 2 provides a rigorous literature review of the blue economy and economic growth. Section 3 provides a detailed overview of the study's methodology. Section 4 presents the results and discussion. Section 5 presents the conclusion.

\section{Literature review}

In the South Asian region, no data have been released on monetary and social estimations of ocean-based businesses and no evaluation has been provided yet that can be calculated in accordance with the concept of the blue economy (Forbes, 1995). The absence of accessible data confines the expectations of related enterprises and this complicates the true assessment of those enterprises in the economic progress at country level. The ocean economy consists of a wide range of resources and assets that have contributed to the development of the world economy. A rough computation indicates that the blue economy is contributing between 3-5\% to global GDP (Patil et al., 2016). India shares a coastal border with six countries, thus providing ample opportunities to harness marine water resources for economic growth through ocean development, export-import trading and the use of natural minerals and energy resources to satisfy domestic needs (Llewellyn et al., 2016). By ensuring a strong and sustainable framework of ocean development, India has the potential to succeed socio-economically. Many South Asian countries border the Bay of Bengal. It has India to its west, northwest and east; Myanmar to its east; Sri Lanka to its southwest; and Indonesia to its southeast (Ghani, 2011). This can create many opportunities for the blue economy to grow, and these states can use the available resources and assets in their respective marine areas. The blue economy is now being recognized around the world, with the Pacific Small Island Developing States (SIDS) and the region of Southern Africa acknowledging its importance. Coastal states reserve the right to investigate and use the assets of their coastal areas.

Fish and fisheries contribute hugely to the livelihoods of individuals in coastal areas. The fisheries in the South Asia region augment livelihoods by $5-8 \%$. In South Asia, the Bay of Bengal is an important resource: India receives approximately half of the fish it produces (1.2 million tons annually) and Myanmar receives approximately 1.1 million tons annually (Funge-Smith et al., 2012). In contrast to India and Myanmar, Bangladesh, Sri Lanka and the Maldives receive annually 0.6 million tons, 0.12 million tons and 0.16 million tons, 
respectively (Krishnamurthy et al., 2018). To ensure quality standards are met, handling and safeguarding processes need to be conducted properly and effectively (Bari, 2017). Legitimate handling and safeguarding can improve the nature of supply, which results in higher GDPs.

Maritime transport manages $80 \%$ of the worldwide product exchange volume and shipped 10 billion tons in 2015 . Rejecting old and unusable boats is an absolute necessity to ensure that ocean-borne businesses can succeed and liberate the global network. Transportation is the scaffold on which extensive world development is based. The coastlines of five South Asian countries (India, Bangladesh, Sri Lanka, Pakistan and the Maldives) represent less than $2 \%$ of the world's total coastline. Coastal areas are responsible for $40 \%$ of business in these countries' respective locales and represent the greater part of their basic financial foundation. South Asia's waterfront districts are exceptionally wealthy. The coastal travel industry in the area has grown by $8 \%$ annually. In 2014, India received the highest number of tourists in the region and Bangladesh received the lowest number (Alam, 2016).

The Changwon Declaration in 2012 placed great emphasis on an ocean-based blue economy and the importance of finding strategies to develop East Asian seas (EAS) (Asia, 2012). In 2014, the Xiamen Declaration also became an important pillar for advocates and allowed them to find new ways to develop cooperation in the region (Stuenkel, 2017). During the 2012 East Asian Seas Congress, the concept of an ocean-based economy was presented (EAS Congress, 2012). The focus was on incorporating environmentally-friendly technology with infrastructure to ensure sustainable development. Institutional changes and policies were also discussed, with the ultimate objective of ensuring sustainable development and protecting coastal areas, the environment, resources and marine ecosystems. The blue economy and its complex relationship with economic growth are usually misunderstood and need clarification (Ayres and Warr, 2010). Other interconnected activities that use oceanbased resources include marine biotechnology and the processing of seafood and salt (Smith-Godfrey, 2016). In addition, the blue economy refers to activities related to ship and boat building and repairing, marine tourism and the creation of maritime laws and services. The blue economy also encompasses activities such as marine research and development (Eikeset et al., 2018). Moreover, it comprises all the relevant sectors that deal with the ocean, including coast guards and the defense forces.

This broader picture of the blue economy gives us insight into the concept as a whole and its importance. As no country wants to waste potential growth opportunities, the blue economy is an important concept for countries with coastal regions. Understanding this importance, the Seychelles and the United Arab Emirates came together and organized a summit in Abu Dhabi in 2014 called the Abu Dhabi Declaration, which emphasized the importance of adapting to and coping with climate change, marine environment preservation and systems related to the blue economy (Small Island Developing States, 2014). The model of the blue economy has gained ground amongst not only the leading nations of the world but also the developing nations. African nations and the SIDS are looking to find opportunities within the blue economy (Ngawi, 2014; Hanif, 2017, 2018a, $2018 \mathrm{~b})$. South Asian nations have relied historically on activities such as fishing and because of their proximity to the Indian Ocean, they have extensive opportunities and huge potential to grow their blue economy. However, without the systems in place to properly organize and implement the blue economy, reaching the potential it offers is highly unlikely.

Fishing is a known livelihood of people in coastal areas. In recent times, fish consumption has surged and demand for fish has grown rapidly. From 1985 to 1997, per capita fish consumption in India increased by $4.3 \%$. Over this period, other South Asian countries also

\section{Economic growth in the SAARC countries}

257 
MABR

5,3 saw an increase in fish consumption, by approximately $3.3 \%$. As then, fish consumption has only increased (Delgado et al., 2003). Aquaculture is a sector that is growing at a substantial rate. It provides solutions to problems such as resource abuse and resource depletion while also providing employment opportunities. South Asia has witnessed dramatic growth trends in the fisheries' sector in comparison to other regions (Funge-Smith et al., 2012).

Some countries such as Sri Lanka and the Maldives, have extensive coastal areas, thus meaning that there have more growth opportunities through marine resources. These countries are looking for opportunities to invest in and boost their economies. According to the UN Resolutions, countries with coastal regions have the right to exploit whichever opportunities they can avail of in the ocean, including mining and fishing (United Nations Convention for the Law of the Sea [UNCLOS] Article 56). Another UN article gives countries with coastlines the right to mine or explore the sea and use its resources (UNCLOS Article 77). Almost all of the world's countries that have coastlines are launching campaigns requesting to extend their continental limits to exploit more resources. This proves that countries have understood the potential of the blue economy and that the situation is expected to improve in the near future. One theory is to put mechanisms in place to share the exploited resources with landlocked countries. This will give equal opportunities to all nations in relation to the blue economy (Schoolmeester et al., 2009). The importance of the development of the blue economy in China has been emphasized by researchers due to the significant contribution that maritime industries make to the Chinese economy. Zhao et al. (2014) and Colgan and Judith (2013) have estimated that ocean-related industries in China have contributed approximately US\$240bn to the economy. The blue economy of China uses more than nine million people and Jiang et al. (2014) found that the contribution of the Chinese marine economy to the national economy increased from $6.46 \%$ to $13.83 \%$ in 2000 2011.

From the review of literature it is clear that different studies show the role of blue economy on economic growth. The present study is an effort to extend the literature by investigating the role of the blue economy in economic growth in SAARC countries. Based on the literature review, the primary hypotheses of this study have been formulated and are presented below:

H1. Total fisheries production (TFP) has a positive significant influence on economic growth.

H2. Aquaculture production (ACP) has a positive significant influence on economic growth.

H3. AFF have a positive significant influence on economic growth.

Thus, the findings of present study could be interesting in formulating an effective policy design to improve the role of the blue economy in the economic growth of SAARC countries.

\section{Research methodology}

Data sources: The study has taken into account annual data from World Development Indicators published by the World Bank, the Food and Agriculture Organization and National Accounts from the OECD. The data collected for the study comprise a panel of SAARC countries (Bangladesh, India, Sri Lanka, Bhutan, Nepal, Pakistan, Afghanistan and the Maldives) from 1995-2018.

Methodology: A general multiple regression model was designed to test the relationships between economic growth and blue economy determinants (ACP; AFF; AFF), along with 
additional control variables (trade and inflation). The research framework is depicted in Figure 1.

In the Solow model of economic growth (Solow, 1956), capital stock (K) increases as part of the output is saved and invested, but it decreases by depreciation. As a result, this study follows the simple form of the Solow Growth Model (Cheung and Yip, 2011: Hanif and Gago-de Santos, 2017). The functional form of our model can be written as follows:

$$
\text { Growth }=f(\text { Labor }, \text { Capital })
$$

The extended version of the model can be written as follows:

$$
\text { Growth }=f(\text { Labor, Capital, BlueEconomy, Z) }
$$

Here,

$$
\text { BlueEconomy }=f(F P, A P, A F F)
$$

And

$$
Z=f(T R D, I N F)
$$

Here we further disaggregate the blue economy (TFP, ACP and AFF) and $Z$ (that denotes to a group of control variables as trade and inflation). The econometric form of the proposed model can be given as follows:

$$
\begin{aligned}
{\log G W_{i, t}=} & \alpha_{i, t}+\beta_{1} \log L_{i, t}+\beta_{2} \log K_{i, t}+\gamma_{1} \log F P_{i, t}+\gamma_{2} \log A P_{i, t}+\gamma_{3} A F F_{i, t} \\
& +\theta_{1} \operatorname{TRD}_{i, t}+\theta_{2} I N F_{i, t}+u_{i, t}
\end{aligned}
$$

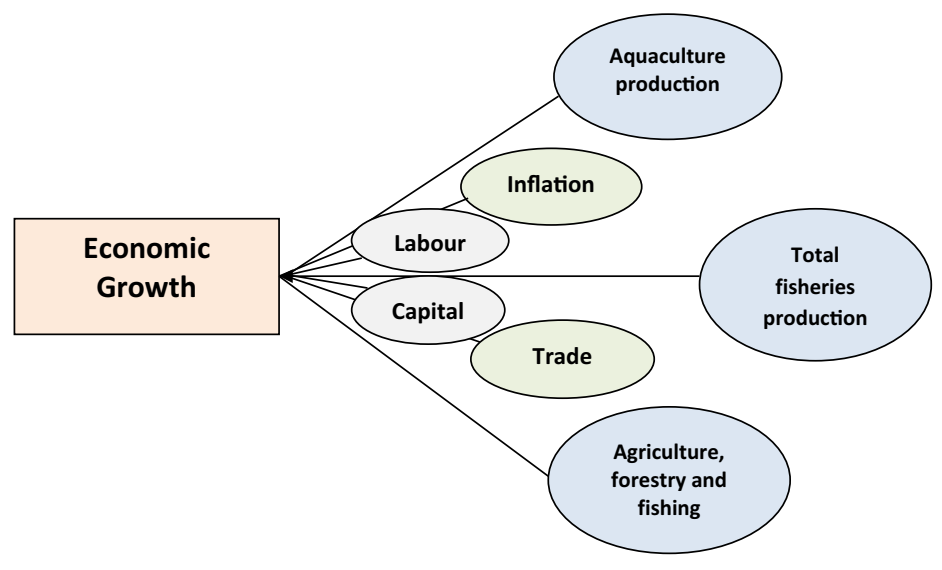

Figure 1. Research framework 
MABR

5,3

wherelog $=$ Normal logarithm, $G W=$ Gross domestic product $\alpha=$ Constant,$L=$ Labour,$K=$ Capital, $F P=$ Total Fisheries production, $A P=$ Aquaculture production, Aquaculture forest and fishing, $T R D=$ Trade, $I N F=$ Inflation, $u=$ Error term, $i=$ Country, $t=$ year .

Here, it is important to mention that in equation (5) we used normal logarithm $(\log )$ because the $\log$ transformation also helps to reduce the problems such as multicollinearity (Asteriou and Hall, 2015). The use of logs will be for when we want to measure elasticities and a good use of this may be estimating the effect of a $1 \%$ increase in independent variable on the percent change in the dependent variable. Technically, taking natural $\log (\mathrm{ln})$ of a rate may be problematic at technical grounds. There are two basic reasons not to choose natural $\log$. Firstly, on theoretical ground one may want to linearize the non-linear relation yet for rates it seems not true. Second reason is statistical when observations are unevenly distributed that is to say from a "normal" perspective: asymmetric, with most observations on one side of the mean and a few outliers on the other side. However, in both cases, taking the log of the variable gives a better shape in terms of normal distribution (symmetry as coincidence of mean and median, variance, etc.). In short, the log transformation helps to examine the impact of independent variables (which are measured in different units) on dependent variable to examine changes in percentage, rather than unit changes (Hanif et al., 2018a, 2018b, 2019). Therefore, the use of logs is great for when we have a marginal effect that is changing in size in units - or put differently, particularly the economic effect of independent variable on dependent variable is somehow related to percent changes, rather than unit changes.

\subsection{List of variables}

Gross Domestic Product (GW) in United States dollars (USD): GDP is the sum of the gross value added by all resident producers in an economy, plus any product taxes and minus any subsidies that are not included in the value of the products. It is calculated without making deductions for either the depreciation of fabricated assets or the depletion and/or degradation of natural resources. Data are in current USD. Dollar figures for GDP are converted from domestic currencies into US $\$$ using official exchange rates. An alternative conversion factor is used for some countries where the official exchange rate does not reflect the effective rate applied to actual foreign-exchange transactions.

Total Fishery Production (FP) in metric tonnes: Total fisheries' production (measured in metric tons) measures the volume of aquatic species caught by a country for all commercial, industrial, recreational and subsistence purposes. The harvests from mariculture, aquaculture and other kinds of fish farming are also included.

Aquaculture production (AP) in metric tonnes: Aquaculture (measured in metric tons) is farming for consumable production of aquatic life, including fish, molluscs, crustaceans and aquatic plants.

Agriculture, forestry and fishing (AFF) as percent of GDP: Agriculture corresponds to International Standard Industrial Classification (ISIC) divisions 1-5 and includes forestry, hunting and fishing, as well as the cultivation of crops and livestock production. Value added is the net output of a sector after adding up all the outputs and subtracting the intermediate inputs. It is calculated without making deductions for the depreciation of fabricated assets or the depletion and/or degradation of natural resources. The origin of value added is determined by ISIC.

Labour (L) in millions: The annual labor force (measured in millions) is used to measure the impact of the labor force on the GDP of developing South Asian countries. 
Capital (K) in USD: The annual rate of gross fixed capital formation in million US\$ is used to examine the influence of capital growth on the GDP in the developing Asian countries.

Inflation rate (INF), consumer index price (CPI) as a percentage: Inflation, as measured by the Consumer Price Index, reflects the annual percentage change in cost to the average consumer when acquiring goods and services that may be either fixed or changed at specified intervals (e.g. annually).

Trade (TRD) as percent of GDP: Trade is the sum of exports and imports of goods and services measured as a percentage of GDP.

\section{Results estimation}

Table 2 provides the descriptive statistics of the variables used to conduct the study. It includes a measure of central tendency (mean) and a measure of variation (standard deviation), along with the variables and the minimum and maximum values.

The mean value of the log of GDP is 24.18. Independent variables such as the log of ACP, have a mean value of 10.03; TFP has a mean value of 11.45 ; $\mathrm{AFF}$ has a mean value of 22.51; INF has a mean value of 6.99; and TRA has a mean value of 56.03. A total of 147 observations were used for the study.

Test for multi-collinearity: A correlation analysis was used to measure the strength and direction of the association between two variables and examine multi-collinearity in the data series. The results of the correlation matrix are provided in Table 3.

Thus, the results of the correlation matrix show that there is no multi-collinearity in the variables.

\begin{tabular}{|c|c|c|c|c|c|c|}
\hline Variables & Observation & Mean & $\mathrm{SD}$ & Minimum & Maximum & \\
\hline $\log G W$ & 147 & 24.186 & 2.180 & 19.529 & 28.459 & \\
\hline $\log F P$ & 147 & 11.455 & 3.793 & 3.951 & 16.1950 & \\
\hline $\log A P$ & 147 & 10.035 & 3.649 & 3.401 & 15.556 & \\
\hline$A F F$ & 147 & 22.519 & 7.347 & 7.426 & 39.041 & \\
\hline $\log L$ & 147 & 13.872 & 5.872 & 4.844 & 21.456 & \\
\hline $\log K$ & 147 & 11.764 & 3.671 & 2.745 & 19.932 & \\
\hline$I N F$ & 147 & 6.992 & 4.652 & -18.108 & 26.418 & Table 2. \\
\hline$T R D$ & 147 & 56.035 & 25.199 & 21.929 & 116.362 & Descriptive statistics \\
\hline
\end{tabular}

\section{Economic growth in the SAARC countries}

Table 2.
e statistics

\begin{tabular}{lrrrrrrrr}
\hline Variables & Log $G W$ & $\operatorname{LogFP}$ & $\log A P$ & AFF & $\operatorname{LogL}$ & $\operatorname{LogK}$ & INF (\%) & $\log T R D$ \\
\hline LogGW & 1.000 & & & & & & & \\
LogFP & 0.216 & 1.000 & & & & & & \\
LogAP & 0.521 & 0.344 & 1.000 & & & & & \\
AFF & 0.338 & -0.212 & -0.321 & 1.000 & & & & \\
LogL & 0.421 & 0.427 & 0.522 & 0.218 & 1.000 & & & \\
LogK & 0.539 & 0.217 & 0.063 & 0.116 & 0.324 & 1.000 & & \\
INF & -0.018 & 0.114 & 0.173 & -0.092 & 0.276 & 0.321 & 1.000 & \\
TRD & 0.275 & -0.418 & -0.399 & 0.041 & 0.345 & 0.456 & -0.035 & 1.000
\end{tabular}

Note: The results show that all variables have a weak to moderate correlation $(-0.5<r<0.5)$

Table 3. Correlation matrix 
MABR

5,3

\section{2}

Table 4.

Test to verify the Gauss-Markov assumptions
Moreover, the study used a pooled ordinary least square (OLS) regression model to examine the role that the blue economy plays in the economic growth of South Asian countries. In the pooled OLS regression, we pooled all of the observations together and ran the regression model, neglecting the cross-section and time-series nature of the data. This is a maximumlikelihood solution that is easy to understand, is one of the best unbiased linear estimators and is more powerful than other regression techniques if Gauss-Markov assumptions are met. The results of the Gauss-Markov assumptions' test are given in Table 4. The key estimation issues for a panel data analysis are usually data normality, serial correlation and heteroscedasticity. Another major issue with this model is that it does not distinguish between the different countries.

The data were found to violate many of the Gauss-Markov assumptions. As such, fixedeffect and random-effect models were applied, and the results are provided in Table 6 . The fixed-effect model allows for either heterogeneity or individuality among the selected group of countries by allowing the intercept value. The fixed term effect is due to the fact that although the intercept value may differ across countries, it does not vary over time (i.e. it is time-invariant). However, the selected countries have a common mean value for the intercept value in the random effect model. To examine the reliability of the results, various diagnostic tests were applied in this study, the outcomes of which are provided in Table 5.

Table 5 shows that the Hausman test was used to check whether a fixed effect or a random effect model is suitable for estimation of results. As the $p$-value of the Hausman test is greater than 0.05 , the random effect model is more efficient and is used to explain the outcome.

\begin{tabular}{lccl}
\hline Diagnostic test & Statistics & Prob. & Conclusion \\
\hline Jarque-Bera normality test Chi2 & 7.103 & 0.02 & Normality is present \\
Breusch-Pagan/Cook-Weisberg test for Heteroscedasticity & 7.03 & 0.00 & Heteroscedasticity is present \\
Breusch-Godfrey LM test for autocorrelation & 136.38 & 0.00 & Serial correlation is present \\
\hline
\end{tabular}

$\log G W / \log F P ; \log A P ; A F F ; \log L ; \log K ; I N F ;$ TRD

i. Results of the Hausman Test

$H_{0}:$ Difference in coefficients not systematic

$\chi^{2}(7)$

0.44

Prob $>\chi^{2}$

0.994

ii. Wooldridge test for serial correlation

$H_{0}$ : No - order autocorreclation

$F(1,7)$

Prob $>F$

iii. Breusch and Pagan LM Test

$H_{0}$ : There exists corss-sectional dependence

$\chi^{2}(7)$

Table 5.

Results of diagnostic

Prob $>\chi^{2}$

iv. Breusch and Pagan LM Test for Random Effect 
Testing for serial correlation and cross-sectional dependence is also essential when examining the reliability of the results. Driscoll and Kraay (1998) stated that serial correlation and cross-sectional dependence have long been recognized as potential problems for panel data. Thus, the Wooldridge test was used for serial correlation in the panel data to determine whether the serial correlation issue was resolved. From Table 5, it is evident that the $p$-value is less than the 0.05 level of significance $(F(1,7)=322.38, p<0.000)$. Thus, we do not accept the null hypothesis and conclude that the data do have a first-order autocorrelation. The cross-sectional dependence was measured using the Breusch-Pagan LM test of independence, which showed that there is cross-sectional dependence across entities, $\chi^{2}(7)=27.962, p$-value $=0.0061$.

The Breusch-Pagan LM test was used to check, which model (the random effect model or the pooled OLS regression model) was suitable. As the $\chi^{2}$ probability value is below the 0.05 level of significance, we accept the alternative hypothesis and conclude that there is evidence of significant differences across countries, meaning that we are unable to run a pooled OLS regression model.

Moreover, Parks (1967) proposed a feasible generalized least square (FGLS) estimator in an attempt to account for heteroscedasticity and temporal and spatial dependence in the residuals of panel models. The FGLS method is typically appropriate for econometric panels if the panel's time dimension " $T$ " is greater than is its cross-sectional dimension " $N$ ", which is almost always the case for macro-economic variables in panel data. Table 6 shows the results based on FGLS estimates.

The results in Table 6 show that fisheries' production has a positive and statistically significant impact on the economic growth of SAARC countries. The results of the FGLS show that if all other factors are constant, then a $1 \%$ increase in fisheries' production improves economic growth by approximately $0.12 \%$. The results highlight that fisheries' production may prove helpful in promoting economic growth by improving livelihood opportunities and food security and alleviating poverty in developing economies. The results showed that fishery is an important sector of SAARC countries' food production. Fisheries sector working as engine of economic growth and annual world-wide trade valium is about US $\$ 171 \mathrm{bn}$, whereas the portion of SAARC counties is about US\$6.5bn, which is only $3.8 \%$ of the total contribution. Although the results show a significant role of fishery in economic growth, there is still need to promote trade unions and cooperation for the

\begin{tabular}{|c|c|c|c|c|}
\hline \multicolumn{5}{|c|}{ Dependent variable: $\log G W$} \\
\hline & Pooled OLS & Fixed effect & Random effect & Feasible GLS \\
\hline $\operatorname{LogFP}$ & $0.401^{* * * *}(7.14)$ & $0.500 * * *(11.04)$ & $0.500 * * *(11.28)$ & $0.121^{* *}(2.82)$ \\
\hline $\log A P$ & $0.159 * * *(2.8)$ & $0.183^{* *}(1.97)$ & $0.192^{* *}(1.87)$ & $0.373^{* * * *}(6.66)$ \\
\hline$A F F$ & $0.051^{* * * *}(5.17)$ & $0.066^{* * * *}(10.74)$ & $0.067 * * *(11.27)$ & $-0.026^{* * *}(4.22)$ \\
\hline $\log L$ & $0.608 * *(2.025)$ & $0.552(1.532)$ & $0.495 * *(1.873)$ & $0.287 *(1.743)$ \\
\hline $\log K$ & $0.325^{*}(1.663)$ & $0.289 * *(1.982)$ & $0.211^{* * * *}(2.792)$ & $0.189 *(1.754)$ \\
\hline$I N F$ & $-0.006(-0.46)$ & $-0.0019(-0.48)$ & $-0.002(-0.49)$ & $-0.0006(-0.03)$ \\
\hline$T R D$ & $0.0063(1.36)$ & $0.0049 * *(2.94)$ & $0.0048^{*}(1.597)$ & $-0.007 * *(-1.743)$ \\
\hline $\mathrm{C}$ & $19.09 * * *(26.88)$ & $18.28 * * *(17.81)$ & $18.63^{* * *}(16.35)$ & $19.18 * * *(34.91)$ \\
\hline$F$-test (model) & 216.48 & 192.03 & 998.13 & 232.25 \\
\hline$F$-test (sign) & 0.000 & 0.000 & 0.000 & 0.000 \\
\hline$R^{2}$ & 0.884 & 0.879 & 0.879 & - \\
\hline$N$ & 147 & 147 & 147 & 147 \\
\hline
\end{tabular}

Notes: Here $t$-statistics given in parentheses; $* p<0.05 ; * * p<0.01 ; * * * p<0.001$
Economic growth in the SAARC countries

263

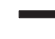


MABR

5,3

264

promotion of fisheries sector. Moreover, the results of this study are consistent with the studies by Funge-Smith et al. (2012). The results also show that a 1\% increase in aquaculture is promoting economic growth by approximately $0.37 \%$ if all other factors are considered constant. The results highlight that SAARC countries have a potential to use aquaculture as an engine of economic growth. More importantly, SAARC countries with respect to geographic location are located in such an area with immense opportunities and possibilities for the development of aquaculture. Thus, regional cooperation on mutual interest like promotion of aquaculture and fisheries may improve the livelihood of millions of individuals and also help to accelerate economic growth to optimal level in the region. The findings also reveal that AFF are important factors that improve economic growth. According to the results of the Pooled OLS, Fixed Effect and Random Effect, in SAARC countries, an improvement of approximately one unit may increase economic growth by approximately $0.051 \%$, $0.066 \%$ and $0.067 \%$ respectively, if all other factors are considered constant. However, the result based on FGLS shows a negative relationship with economic growth, the change in sign from positive to negative indicates the presence of heteroscedasticity and autocorrelation. This indicate that the desirable properties of FGLS can only be shown to hold asymptotically when hypothesis testing based on normal distribution rather than its small sample counterparts. Thus, a change in sign of agriculture, forestry and fishing variable while remaining highly significant indicates the issue of serial correlation in the model. More importantly, the results of the pooled OLS, the fixed and random effect models are consistent and show the significant and positive impact of AFF on economic growth.

In short, the results of this study accept the null hypotheses $H 1, H 2$ and $H 3$ and confirm the significant role of the blue economy in improving economic growth in SAARC economies. The results support the findings of Ayres and Warr (2010), Ngawi (2014), SmithGodfrey (2016), Patil et al. (2016), Stuenkel (2017). The findings also highlight how the proper management and utilization of the oceans' resources helps to promote economic growth and address challenges of food insecurity by improving the provision of food in developing South Asian countries. Moreover, this study highlights the promotion of various areas of the blue economy that could help meet Sustainable Development Goal (SDG) 14. However, a joint effort is required to assess each sector of the blue economy and decide, based on each sector's priorities and circumstances, which ones to prioritize. This prioritization will promote the role of different sectors of the blue economy, thus fostering economic growth.

The results show that both labor and capital play significant and positive roles in the promotion of economic growth in developing South Asian countries. However, a negative and statistically insignificant relationship was found between inflation and economic growth. This is similar to the findings of Mario and Josipa (2017), Khan and Senhadji (2002) and Andrés and Hernando (1997), who also found a weak and negative correlation between inflation and economic growth. It was also found that trade has a significant and positive effect on economic growth - a finding that is similar to studies by Rassekh (2007), Rigobon and Rodrik (2005) and Vamvakidis (2002), who also found a positive relationship between trade and economic growth. The FGLS model has an $F$-statistic of approximately $232.25(p=$ 0.000 ), which indicates that the estimated model is best fit. Overall, the study data are highly consistent due to greater values of $R^{2}(0.844,0.879$ and 0.879$)$. In comparison, the pooled OLS model indicates the highest consistency (0.844) compared to the fixed and random effect models (0.879). 


\section{Conclusion}

A blue economy can contribute significantly to the growth of an economy if a country's blue resources are mapped and integrated properly within a strong institutional framework and based on concrete policies and research. Thus, there is potential for infrastructural growth. This will also generate employment and help eradicate poverty through the social inclusion of the inhabitants of coastal regions. This study concludes that SAARC countries have the potential to implement a blue economy that will lead to economic growth in the region, but it requires strong political commitments, concrete research, societal awareness and positive attitudes. Thus, if SAARC countries make proper use of their resources, they will experience a faster rate of progress. In short, this study infers that South Asia in general has both the possibility and scope to execute the concept of the blue economy. However, solid political responsibilities, in-depth examinations, cultural mindfulness and a positive frame of mind to upgrade the reliance on blue economy are required to ensure long-term success. The sustainable management of ocean resources requires collaboration across nation-states, and this will be helpful in understanding the concept of the blue economy and its importance in promoting economic growth, meeting SDG 14 and improving the livelihoods of people by ensuring food security.

\section{References}

Alam, M.K. (2016), Ocean/Blue Economy for Bangladesh, Ministry of Foreign Affairs, Government of the peoples' republic of Bangladesh.

Andrés, J. and Hernando, I. (1997), "Does inflation harm economic growth? Evidence from the OECD", NBER working paper no. 6062, June.

Asia, R.R.C.E. (2012), "The Changwon declaration in action for the wise use of wetlands", Report of the Meeting of the Changwon Declaration Network on Human Well-Being and Wetlands (20092011), p. 200.

Asteriou, D. and Hall, S.G. (2015), Applied Econometrics, Palgrave Macmillan, New York, NY.

Ayres, R.U. and Warr, B. (2010), The Economic Growth Engine: How Energy and Work Drive Material Prosperity, Edward Elgar Publishing.

Bari, A. (2017), "Our oceans and the blue economy: opportunities and challenges", Procedia Engineering, Vol. 194, pp. 5-11.

Behnam, A. (2012), "Building a blue economy: strategy, opportunities, and partnerships in the seas of East Asia", The East Asian Seas Congress 2012, Changwon.

Bose, S. and Jalal, A. (2017), Modern South Asia: history, Culture, Political Economy, Routledge.

Cheung, S.M.S. and Yip, T.L. (2011), "Port city factors and port production: analysis of Chinese ports", Transportation Journal, Vol. 50 No. 2, pp. 162-175.

Colgan, C.S. and Judith, T. (2013), "Understanding the ocean economy within regional and national", Presentations, Vol. 1, available at: https://cbe.miis.edu/cbe_presentations/1 (accessed 4 December 2019).

Delgado, C.L., Wada, N., Rosegrant, M.W., Meijer, S. and Ahmed, M. (2003), Outlook for Fish to 2020: meeting Global Demand, Vol. 15, Intl food policy res inst.

Driscoll, J.C. and Kraay, A.C. (1998), "Consistent covariance matrix estimation with spatially dependent panel data”, Review of Economics and Statistics, Vol. 80 No. 4, pp. 549-560.

EAS Congress (2012), "Building a blue economy: strategy, opportunities and partnerships in the seas of East Asia”, Proceedings of the Fourth Ministerial Forum on the Sustainable Development of the Seas of East Asia, Changwon City, Republic of Korea.
Economic
growth in the
SAARC
countries

265 
MABR

5,3

Eikeset, A.M., Mazzarella, A.B., Davíðsdóttir, B., Klinger, D.H., Levin, S.A., Rovenskaya, E. and Stenseth, N.C. (2018), "What is blue growth? The semantics of 'sustainable development' of marine environments", Marine Policy, Vol. 87, pp. 177-179.

European Union (2018), "The 2018 annual economic report on EU blue economy: 5", available at: https://ec.europa.eu/maritimeaffairs/sites/maritimeaffairs/files/2018-annual-economic-report-onblue-economy_en.pdf (accessed 7 March 2020).

Everest-Phillips, M. (2014), Small, so Simple? Complexity in Small Island Developing States, UNDP Global Centre for Public Service Excellence.

Forbes, V.L. (1995), The Maritime Boundaries of the Indian Ocean Region, NUS Press, Singapore.

Funge-Smith, S., Briggs, M. and Miao, W. (2012), "Regional overview of fisheries and aquaculture in Asia and the Pacific 2012", Asia-Pacific Fishery Commission (APFIC), available at: www.fao.org/ 3/i3185e/i3185e00.htm (accessed 8 December 2019).

Ghani, E. (2011), Reshaping Tomorrow: Is South Asia Ready for the Big Leap?, Oxford University Press, New Delhi.

Golden, J.S., Virdin, J., Nowacek, D., Halpin, P., Bennear, L. and Patil, P.G. (2017), "Making sure the blue economy is green", Nature Ecology and Evolution, Vol. 1, p. 17.

Hanif, I. (2017), "Economics-energy-environment nexus in Latin America and the Caribbean”, Energy, Vol. 141, pp. 170-178.

Hanif, I. (2018a), "Energy consumption habits and human health nexus in Sub-Saharan Africa", Environmental Science and Pollution Research, Vol. 25 No. 22, pp. 21701-21712.

Hanif, I. (2018b), "Impact of fossil fuels energy consumption, energy policies, and urban sprawl on carbon emissions in East Asia and the pacific: a panel investigation”, Energy Strategy Reviews, Vol. 21, pp. 16-24.

Hanif, I. and Gago-de Santos, P. (2017), "Impact of fiscal decentralization on private savings in a developing country: some empirical evidence for the case of Pakistan", Journal of South Asian Development, Vol. 12 No. 3, pp. 259-285.

Hanif, I., Aziz, B. and Chaudhry, I.S. (2019), "Carbon emissions across the spectrum of renewable and nonrenewable energy use in developing economies of Asia”, Renewable Energy, Vol. 143, pp. 586-595.

Henderson, V., Storeygard, A. and Weil, D.N. (2011), “A bright idea for measuring economic growth", American Economic Review, Vol. 101 No. 3, pp. 194-199.

Hoshino, M. (2011), "Measurement of GDP per capita and regional disparities in China, 1979-2009", Research Institute for Economics and Business Administration, Kobe University Discussion Paper Series, available at: http://www.rieb.kobe-u.ac.jp/academic/ra/dp/English/DP2011-17.pdf

Howard, B.C. (2018), "Blue growth: Stakeholder perspectives”, Marine Policy, Vol. 87, pp. 375-377.

Jayawardena, R., Byrne, N.M., Soares, M.J., Katulanda, P. and Hills, A.P. (2013), "Prevalence, trends and associated socio-economic factors of obesity in South Asia”, Obesity Facts, Vol. 6 No. 5, pp. 405-414.

Jiang, Y.J., He, W., Liu, W.X., Qin, N., Ouyang, H.L., Wang, Q.M., Kong, X.Z., He, Q.S., Yang, C., Yang, B. and Xu, F.L. (2014), "The seasonal and spatial variations of the phytoplankton community and their correlation with environmental factors in a large eutrophic Chinese lake (lake Chaohu)", Ecological Indicators, Vol. 40, pp. 58-67.

Kathijotes, N. (2013), "Keynote: Blue economy-environmental and behavioral aspects towards sustainable coastal development", Procedia - Social and Behavioral Sciences, Vol. 101, pp. 7-13.

Keen, M.R., Schwarz, A.M. and Wini-Simeon, L. (2018), "Towards defining the blue economy: practical lessons from pacific ocean governance", Marine Policy, Vol. 88, pp. 333-341.

Khan, H.A. (2005), "Assessing poverty impact of trade liberalization policies: a generic macroeconomic computable general equilibrium model for South Asia (No. 22)", ADB Institute Discussion Papers. 
Khan, M.S. and Senhadji, A. (2002), "Inflation, financial deepening and economic growth", Banco de Mexico Conference on Macroeconomic Stability, Financial Markets and Economic Development. November, Vol. 1213.

Krishnamurthy, R.R., Jonathan, M.P., Srinivasalu, S. and Glaeser, B. (Eds) (2018), Coastal Management: Global Challenges and Innovations, Academic Press.

Lillebø, A.I., Pita, C., Rodrigues, J.G., Ramos, S. and Villasante, S. (2017), "How can marine ecosystem services support the blue growth agenda?”, Marine Policy, Vol. 81, pp. 132-142.

Llewellyn, L.E., English, S. and Barnwell, S. (2016), "A roadmap to a sustainable Indian ocean blue economy", Journal of the Indian Ocean Region, Vol. 12 No. 1, pp. 52-66.

McGlade, J., Werner, B., Young, M., Matlock, M., Jefferies, D., Sonneman, G., Martinez-Aldaya, M., Pfister, S., Berger, M., Farell, C. and Hyde, K. (2012), Measuring Water Use in a Green Economy, a Report of the Working Group on Water Efficiency to the International Resource Panel, UNEP.

Mario, S. and Josipa, M. (2017), "Relationship between inflation and economic growth; comparative experience of Italy and Austria", FIP-Journal of Finance and Law, Vol. 5, pp. 91-101.

Mulazzani, L., Trevisi, R., Manrique, R. and Malorgio, G. (2016), "Blue growth and the relationship between ecosystem services and human activities: the Salento artisanal fisheries case study", Ocean and Coastal Management, Vol. 134, pp. 120-128.

Murry, D.A. and Nan, G.D. (1994), "A definition of the gross domestic product-electrification interrelationship", The Journal of Energy and Development, Vol. 19 No. 2, pp. 275-283.

Ngawi, D.K.K. (2014), "Petunjuk Teknis Program Restu Ibu (Gerakan Tuntas Penanganan Gizi Buruk)", available at: https:/media.neliti.com/media/publications/78665-ID-pelaksanaan-program-gerakantuntas-gizi.pdf (accessed 10 December 2019).

OECD (2017), “How's Life? 2017: measuring well-being”, OECD Publishing, Paris, available at: www. oecd-ilibrary.org/economics/how-s-life-2017/summary/english_29ece891-en?parentId=http\%3A $\% 2 \mathrm{~F} \% 2 \mathrm{Finstance}$.metastore.ingenta.com $\% 2 \mathrm{~F}$ content $\% 2 \mathrm{~F}$ publication $\% 2 \mathrm{Fhow}$ _life-2017-en (accessed 4 December 2019).

Parks, R.W. (1967), "Efficient estimation of a system of regression equations when disturbances are both serially and contemporaneously correlated", Journal of the American Statistical Association, Vol. 62 No. 318, pp. 500-509.

Parletta, N. (2019), "Making the blue economy sustainable", available at: https://www.forbes.com/sites/ natalieparletta/2019/06/21/making-the-blue-economy-a-sustainable-reality/\#337b0b9826f8 (accessed 8 December 2019).

Patil, P.G., Virdin, J., Diez, S.M., Roberts, J. and Singh, A. (2016), Toward a Blue Economy: A Promise for Sustainable Growth in the Caribbean, World Bank.

Pauli, G.A. (2010), The Blue Economy: 10 Years, 100 Innovations, 100 Million Jobs, Paradigm publications.

Rassekh, F. (2007), "Is international trade more beneficial to lower-income economies? An empirical inquiry", Review of Development Economics, Vol. 11 No. 1, pp. 159-169.

Rigobon, R. and Rodrik, D. (2005), "Rule of law, democracy, openness, and income: estimating the interrelationships1", The Economics of Transition, Vol. 13 No. 3, pp. 533-564.

Sarker, S., Bhuyan, M.A.H., Rahman, M.M., Islam, M.A., Hossain, M.S., Basak, S.C. and Islam, M.M. (2018), "From science to action: exploring the potentials of blue economy for enhancing economic sustainability in Bangladesh", Ocean and Coastal Management, Vol. 157, pp. 180-192.

Schoolmeester, T., Baker, E., Fabres, J., Halvorsen, Ø., Lønne, Ø., Poussart, J.N., Pravettoni, R., Sørensen, M. and Thygesen, K. (2009), Continental Shelf: The Last Maritime Zone, UNEP/GRID-Arendal, Norway.

Singh, R. (2019), "India's Maritime security and policy: an imperative for the blue economy", India in South Asia, Springer, Singapore, pp. 269-289. 
MABR

5,3
Small Island Developing States (2014), available at: https://sustainabledevelopment.un.org/content/dsd/ dsd_aofw_sids/sids_sidsnet.shtml

Smith-Godfrey, S. (2016), "Defining the blue economy", Maritime Affairs: Journal of the National Maritime Foundation of India, Vol. 12 No. 1, pp. 58-64.

Solow, R.M. (1956), “A contribution to the theory of economic growth”, The Quarterly Journal of Economics, Vol. 70 No. 1, pp. 65-94.

Soma, K., van den Burg, S.W., Hoefnagel, E.W., Stuiver, M. and van der Heide, C.M. (2018), "Social innovation - a future pathway for blue growth?", Marine Policy, Vol. 87, pp. 363-370.

Stuenkel, O. (2017), “The BRICS leaders Xiamen declaration: an analysis”, Blog Post-Western World.

Toropova, C., Meliane, I., Laffoley, D., Matthews, E. and Spalding, M. (2010), Global Ocean Protection: present Status and Future Possibilities, IUCN.

Vamvakidis, A. (2002), "How robust is the growth-openness connection? Historical evidence", Journal of Economic Growth, Vol. 7 No. 1, pp. 57-80.

Van-den-Burg, S.W.K., Aguilar-Manjarrez, J., Jenness, J. and Torrie, M. (2019), “Assessment of the geographical potential for co-use of marine space, based on operational boundaries for blue growth sectors", Marine Policy, Vol. 100, pp. 43-57.

Voyer, M. and van Leeuwen, J. (2019), "Social license to operate' in the blue economy”, Resources Policy, Vol. 62, pp. 102-113.

Wong, P.K., Ho, Y.P. and Autio, E. (2005), "Entrepreneurship, innovation and economic growth: evidence from GEM data", Small Business Economics, Vol. 24 No. 3, pp. 335-350.

World Bank (2019), "The world bank in South Asia”, Updated on October 11, 2019, available at: https:// www.worldbank.org/en/region/sar/overview (accessed 4 December 2019).

Zhao, R., Hynes, S. and He, G.S. (2014), "Defining and quantifying China's ocean economy", Marine Policy, Vol. 43, pp. 164-173.

\section{Corresponding author}

Majed Alharthi can be contacted at: mdalharthi@kau.edu.sa

For instructions on how to order reprints of this article, please visit our website: 